NATL INST OF STANO \& TECH

NBSIR 84-2886

\title{
Benefits Perceived by U.S. Industry From Participating in International Standards Activities
}

Patrick W. Cooke

U.S. DEPARTMENT OF COMMERCE

National Bureau of Standards

Office of Product Standards Policy

Gaithersburg, Maryland 20899

September 1984

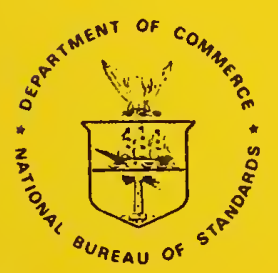

U.S. DEPARTMENT OF COMMERCE

\section{- QC NATIONAL BUREAU OF STANDARDS}

100

.456 

NBSIR 84-2886

BENEFITS PERCEIVED BY U.S.

INDUSTRY FROM PARTICIPATING IN

INTERNATIONAL STANDARDS ACTIVITIES

Patrick W. Cooke

U.S. DEPARTMENT OF COMMERCE

National Bureau of Standards

Office of Product Standards Policy

Gaithersburg, Maryland 20899

September 1984

U.S. DEPARTMENT OF COMMERCE, Malcolm Baldrige, Secretary NATIONAL BUREAU OF STANDARDS. Emest Amblor, Director 

Abstract -

1. Introduction - 1

2. Background - 2

2.1 Relationship to U.S. Competitiveness in Export Trade -.-.-.--- 2

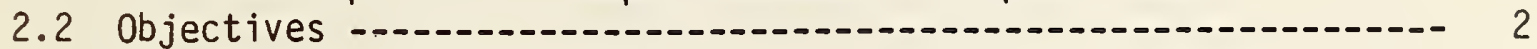

2.3 International Organizations Involved in Standardization ---.--- 3

3. Survey Process -

4. Profile of Companies Surveyed -..- 4

5. Interview Proceedings - 5

6. Survey Findings -

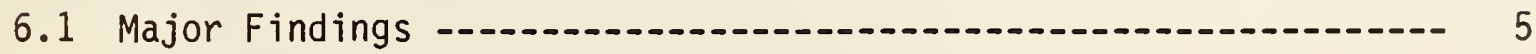

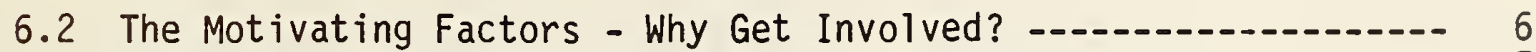

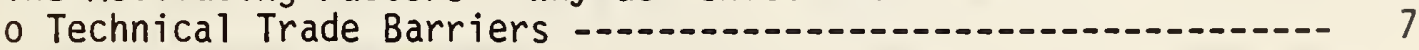

o Competitive Strategies -............ 7

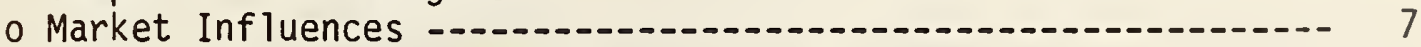

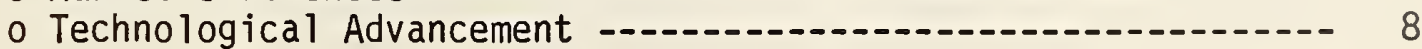

6.3 The Benefits - Diverse Opportunities for Participants---_-_-_--- 8

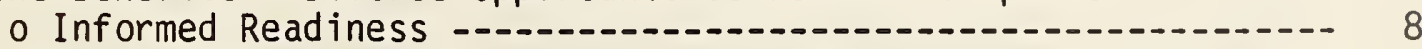

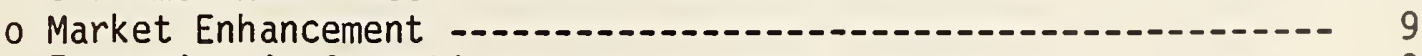

- Economies in Operation

6.4 Disadvantages -...-. 9

7. Other Studies Related to Benefits Perceived by Industry from

Standards Participation -..-...- 9

8. Conclusions and Recommendations - 11

8.1 Conclusions --

8.2 Recommendations -...-.-.-. 12

9. Future Studies --1-1 13

10. References --1 13 


\section{Tables}

Table 1 Characteristics of Companies - 15

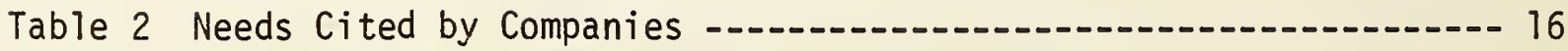

Table 3 Benefits from Participation -

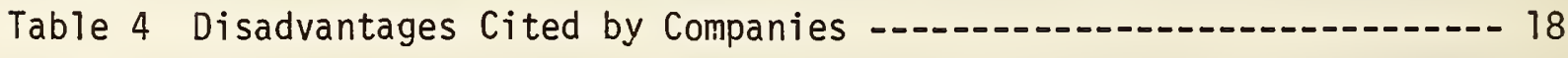




\title{
BENEFITS PERCEIVED BY U.S. INDUSTRY \\ FROM PARTICIPATING IN INTERNATIONAL STANDARDS ACTIVITIES
}

\author{
Patrick W. Cooke \\ National Bureau of Standards \\ Gaithersburg, MD 20899
}

\begin{abstract}
This report describes the results of a limited study to assess the extent to which U.S. industry profits by virtue of participation in the committee activities of international standardization organizations. The substantial trade benefits that can accrue are identified and evaluated in terms of the needs of the firms surveyed and the potential opportunities for new or increased foreign trade. Recommendations are given for industry to become more aware of the cost-effectiveness of participation and to extend the potential benefits to other firms and industries.
\end{abstract}

Key Words: Benefits; cost-effectiveness; exports; foreign trade; international bodies; international standards; standards development; trade barriers; U.S. industry

\section{INTRODUCTION}

One of the major goals of the U.S. Department of Commerce (DOC) is to "increase America's competitiveness in the world economy" by establishing trade expansion as a national priority. The Trade Agreements Act of 1979 assigns responsibilities to DOC to promote a healthy U.S. economy and increased trade opportunities for U.S. industry. The Department has delegated to the Office of Product Standards Policy (OPSP) in the National Bureau of Standards responsibility for carrying out specific obligations. These include tasks under Section 413 [1] * of the Trade Agreements Act for monitoring the adequacy of representation of U.S. interests in international standards activities, particularly with regard to the potential impact on the international trade of the United States.

The Standards Code and Information (SCI) Program in OPSP carries out a number of duties associated with the Trade Agreements Act and the GATT "Standards Code."[2] SCI maintains a reference collection containing information on standards and certification systems and responds to requests for information; disseminates notifications of proposed foreign regulations which might significantly affect trade; and operates the Technical Office for non-agricultural products. Technical activities include analyses, research, and assistance to government and private-sector groups in commenting on proposed or existing foreign regulations in efforts to overcome or eliminate technical barriers to trade. As part of this activity, SCI undertook to obtain and examine the benefits and

* Numbers in brackets refer to the literature references listed at the end of this report. 
costs of international standardization activities to U.S. industry participants which might provide a basis for guiding future efforts in encouraging participation.

This report is the second in a series bearing on an assessment of the adequacy of information and of representation in activities which might be significant to U.S. trade. An earlier report [3] identified major export categories as defined by DOC's International Trade Administration and matched them with reported levels of standardization activity open to U.S. participation. Although there was no evidence of underrepresentation, the emphasis was skewed in the areas of newer technology and those product categories having high export value. Subsequent studies in this series will examine and compare standards-related requirements for various product categories in selected foreign countries.

\section{BACKGROUND}

\subsection{Relationship to U.S. Competitiveness in Export Trade}

The U.S. share of world exports of manufactured goods has declined significantly since 1980. The U.S. merchandise trade deficit for 1983 was a record $\$ 69.4$ billion, and projections for 1984 indicate that the trade deficit will exceed $\$ 100$ billion. [4] These figures imply the loss of an estimated 1.3 million export-related jobs. According to Department of Commerce (DOC) studies, two of every five jobs lost in the latest recession were due to declining exports. Economic conditions have made clear that increases in sales abroad are essential to American workers, corporations, and their communities.

To compete effectively in foreign markets, American companies usually must learn to cope with unfamiliar situations. Foreign exchange, political risks, regulations, and differences in language and culture can all pose obstacles to exporters. In this environment, standards and related areas of technical regulations, such as testing and certification, may have considerable impact as disincentives or barriers to U.S. trade. But such standards may also play a facilitating role in the increasingly international framework of the global marketplace. Standards development at the international level has the potential for many opportunities beyond the international agreements on technical issues reached in a particular field. Examples of these opportunities include developing foreign contacts and information gathering. Because international standards are adopted by many countries and used in their inspection, approval, and certification systems, they tend to govern product acceptance throughout much of the world.

\subsection{Objectives}

Information regarding the benefits which demonstrably or potentially accrue to the relatively few U.S. firms [5] that have made the investment to participate in international standardization has not previously been collected, assessed or disseminated. This study was therefore initiated to determine benefits that may be realized from involvement, of ten at the cost of a significant financial investment for some smaller companies. Specific objectives for the project were:

1. To ascertain (quantitatively insofar as possible) how a limited number of U.S. firms benefit or are injured by virtue of their participation in international standards activities. 
2. To identify any possible trends or relationships between participation in international standards activities and trade benefits which might be generally applicable to other industries and firms.

3. To identify potential opportunities for new or increased trade by extrapolation of findings to other industries and firms not now involved (or perhaps not optimally involved) in international standards activities.

Interviews and discussions with corporate personnel having direct responsibility and involvement in international standards work was the source of all project information. Companies that are not active in international standards work or those who at one time were active and are no longer involved were not interviewed.

\subsection{International Organizations Involved in Standardization}

More than 200 international organizations promulgate international standards. [6] of these, the International Standards Organization (ISO) and the International Electrotechnical Commission (IEC) are perhaps the most widely recognized. Standards are also developed and issued by private regional organizations, such as the European Tyre and Rim Technical Organization (ETRTO), and regional treaty organizations, such as the Pan American Standards Commission (COPANT).

International and regional standards organizations adopt their own membership rules, which may or may not permit representation by or from the United States. For example, ISO and IEC limit membership to national standards bodies (NSB): the American National Standards Institute (ANSI) serves in that coordinating capacity for the United States. U.S. citizens from both the public and private sectors participate in a large number and variety of ISO and IEC technical committees, subcommittees, and working groups, a 11 administered by ANSI as the U.S. member body. Other international standards organizations may al low participation by representatives of U.S. firms, government agencies, non-profit associations, or diplomatic representatives.

Membership classifications include voting and non-voting; full, partial, or limited membership; and observer status. The level of membership and the degree of activity exercised by representatives is a function not on $1 y$ of the organizational rules, but also of membership fees and costs attendant on travel to meetings overseas. These factors may be influential in acceptance of Chairmanships of committees, subcommittees, and working groups and service as Secretariats. In general, full voting membership and active participation on committees and in working groups reflect the highest degree of interest and imply more effectiveness in influencing results than obtainable through lesser participation.

This report relates primarily to benefits resulting from participation at the international level, primarily in ISO and IEC activities. 


\section{3.. SURVEY PROCESS}

In conjunction with ANSI and the Industry Functional Advisory Committee on Standards of DOC, volunteers were sought from all industry sectors to participate in the survey. Letters were sent to TAG chairmen from industry sectors and others with known active experience in ISO or IEC technical committees. NBS staff members who serve on technical committees of international standards development bodies were also contacted. Preliminary informal telephone discussions with officials of twenty-four companies led to final detailed, person-to-person interviews with standards officials from five firms. In one case, at least two on-site discussions took place over a number of months. Follow-up discussions verified specific information.

\section{PROFILE OF COMPANIES SURVEYED}

The five firms contributing to this study represent different industrial sectors: electronic components, process control equipment, building products and materials, medical devices, and outdoor powered equipment. Their characteristics are summarized in Table 1. All have been engaged in significant export trade for many years. Total annual sales approximate $\$ 4$ billion, and all but one organization have manufacturing operations abroad. The companies have been active in either ISO or IEC technical committees for at least 5 years, and in some cases their representatives have served as Committee Chairman or Secretariat. None of them covers expenses for international standards functions by a specific line item in company budgets. In three of the companies, expenses are charged against the Quality Assurance Department, in another the Research and Development Department, and in the fifth company all standards work is supported by the Marketing and Product Planning Department. In two cases, some travel expenses are partially supported by the cognizant industry trade association. In four of the organizations, the person responsible for international standards activities reports directly to a corporate vice president, whereas the fifth is four levels removed from senior management. (This is a large organization with many diverse operating divisions.) In one of the companies, the person responsible for standards activities frequently meets with the Board of Directors to keep them abreast of the company's actions in U.S. and multinational standards organizations.

One of the companies has been active in international standardization activities for over 25 years. Its philosophy is that customers should be able to buy the company's products throughout the free world and that the product should have the same basic design and performance characteristics wherever purchased. For this reason, the company retains strong central control over all product design and development functions. 


\section{INTERVIEW PROCEEDINGS}

Information was gathered from each of the five companies during person-to-person interviews of at least two hours each. The interview sessions were relatively non-structured and open-ended. An outline was followed to assure that the same topics were covered with each organization's representatives. The discussion topics covered the following areas:

0 History and extent of participation by company

0 Influences and motivations - when, why, how?

o Company organizational setting

- Identification of benefits - primary/secondary

o Classification of benefits

- Product design or application/markets/competition

- Company policy, procedures, budgets

- Accountability/commitment of management

- Expenditures for participation; justifications, budgets

- Domestic impacts (i.e., U.S. product changes resulting from adoption of international standards)

- Domestic standards vis-a-vis international standards

- Future trends

- Problems due to participation (i.e., schedules, agendas, voting policies, meeting locations)

There was optimism at the outset of the project that quantifiable data would be obtainable even though professionals active in standards organizations over long periods of time cautioned that this might not be possible. As the interviews progressed, they reinforced a growing realization that benefits are not readily measurable. Nonetheless, the interviewees at the same time reinforced one another's subjective views of benefits and established a pattern which, in retrospect, substantiated a practical set of constructs which might have been postulated in advance.

The company experts were all exceedingly frank and open in their responses to questions and in volunteering supporting material. Their interest in the study objectives was high, and they all desired to be informed about the outcome.

\section{SURVEY FINDINGS}

\subsection{Major Findings}

1. All of the organizations contacted in developing this study, including the five firms interviewed in depth, unanimously indicated that the benefits from participating in international standards activities are substantial, but that they cannot be quantified. There is no truly suitable method of accounting readily available to monitor all the costs and benefits involved. All respondents independently emphasized that the benefits from participation in international standardization activities, though substantial, do not lend themselves to direct evaluation because of the elusive nature of the activity and the variety of interfaces, particularly for multinational corporations. 
2. The companies maintained that quantitative calculation of direct benefits is not possible because of the wide dispersion of benefits as well as a large number of intangible qualities. It does not appear to be possible to attribute simple profitability, similar to other business investment situations, because of inability to collect (or even estimate) the appropriate revenue and cost data necessary. One firm initially volunteered to collect cost and benefit data for this study over a nine month period. At the final interview, however, the company reported that it had not been feasible to collect and report such data in any meaningful fashion.

3. The companies individually and collectively were capable of identifying the nature and variety of a number of perceived benefits even though quantification was not possible.

4. Even if "return on investment" figures or data on "increased sales" were available, such indices would reflect only a small part of the value of participation as experienced by these companies. Each member of the group stated that the intangible and other undocumented benefits were sufficiently substantial to make continued participation worthwhile. In addition, they maintained that their involvement in international standards bodies was a necessary part of their business abroad. Some indicated that it would be impossible to calculate the extent of financial and other effects on foreign sales, markets, product recognition and company good will that would have resulted from lesser participation in international standardization activities.

5. All interviewees strongly intend to continue participation in the work of international standards bodies. In this resolve they reflect strong support and backing of their respective corporate managements and, in one instance, from the corporate Board of Directors.

6. Companies expressed interest in international product standards and test methods as doubly beneficial to U.S. industry sectors, both for permitting export on a world-wide basis and for establishment of profitable manufacturing operations abroad.

\subsection{The Motivating Factors -- Why Get Involved?}

The individuals interviewed and their organizations are motivated to participate in international standardization efforts in a variety of ways. Some commonality of needs can be cited, whereas some reasons are quite specific to individual organizations. Table 2 summarizes needs indicated in the five interviews. For the discussion and analys is which follow, these needs have been arranged into four basic, but closely related, categories:

Technical Trade Barriers ( $T$ ); Competitive Strategies (C); Market Influences (M); and Technological Advancement $(A)$. 
The predominant perceived needs or problems were related to technical barriers to trade. Almost one-half of the mentioned factors were in this area. There was unanimous agreement on the desirability of obtaining universally recognized product or test method standards so that a company could ship its products anywhere in the world, rather than having to deal individually with the complex array of regulations now in place in many different countries. Other factors that contribute to technical trade barriers are in the area of national regulations requiring type certification, product testing and other regulatory approvals which differ from country to country. For example, national medical device regulatory processes differ significantly even after the adoption of international standards. Clinical procedures, sterilization requirements, approved compounds lists, approvals by various health ministries, etc., differ from one country to another and from culture to culture. Similarly, for building products most countries still have their own national tests for evaluating fire performance and a maze of other buildings codes and standards at the national or local level. U.S. companies exporting to these markets are required to follow many separate testing programs because there is no basis for recognizing equivalency among the different test regimens of the various countries involved.

\section{- Competitive Strategies}

After concerns about perceived technical (non-tariff) barriers, the respondents most frequently cited factors characterized here as "competitive strategies," accounting for approximately one-fourth of the total. These reasons include defensive actions taken to counter foreign competitors who make inroads into domestic and other markets through cross-1icensing arrangements and as vendors to manufacturers of integrated equipment and systems. Companies have also found that domestic competitors who are successful in export trade are frequently involved in international standardization activities. They feel compelled to participate too, if only to keep up with their competition, whether foreign or domestic or both. Some firms characterized this as a purely "defensive action" to meet or beat the competition in the area of standards. Others stated that they need to know what others in their business are doing. Harmonizing international standards with U.S. standards was also considered a competitive strategy.

\section{- Market Influences}

The category entitled "market influences" includes such factors as the need for market expansion because domestic market share was becoming fixed and the rapid movement of large-customers (end-item users) to adopt international standards in their procurement specifications. These influences also require the companies to maintain product compatibility through electro-mechanical interfaces in order to market abroad. Some of the companies have an essential need to be aware of all user (i.e., customer) requirements regarding the technical application of their products. In this regard, some users exert significant influence in international standards activities which, in turn, eventually affects U.S. domestic standards. One company's policy is dictated by marketing conditions to centralize product design and development activities so that 
its customers can buy their products anywhere in the world and be assured of the same performance characteristics. Other market influences included the fact that a company had a long established overseas presence in several markets. Their involvement was predicated on their concern to protect existing overseas markets.

\section{- Technological Advancement}

The three technology-intensive companies gave state-of-the-art advances in technology as a prime reason for being active in international standards work. In their industry sectors, the rapidity of technology advances may lead to the development of foreign national, regional, or international standards which could profoundly affect trade overseas. These organizations find it imperative to learn through participation the nature of technological advances and their prospective impact on the companies' ability to adapt and compete. They expect to prosper by working for adoption of provisions favorable to their own technological approaches or by modifying their processes as may be necessary. Others may employ strategies to slow down technology improvements via standards.

\subsection{The Benefits -- Diverse Opportunities for Participants}

The companies mentioned a number of advantages deriving from their participation in international standardization. These are individually listed by company in Table 3. As indicated above, the benefits are for the most part intangible. Although they believe that economic gains accrue from involvement, they were not able to document them quantitatively. For instance, they all felt that removal of technical trade barriers broaden their available market base for exporting and puts all suppliers on a fairer competitive basis. Other business factors also contribute to the expansion of markets - not all market gains can be attributed solely to removal of technical trade barriers via international standards. Other reported economic gains result from reduced manufacturing and design costs and the efficiencies from not operating parallel production lines to meet multiple product designs for foreign and domestic markets.

The individual benefits from those given in Table 3 can be classified as Informed Readiness (R), Market Enhancement (M) and Economics in Operation (E).

\section{- Informed Readiness}

The most significant advantage cited has been classified as "informed readiness." The benefits in this category were not given a dollar value, but the respondents held them to be invaluable to their international business operations. These benefits include influencing the business affairs of standards committees (i.e., agendas, voting, scheduling of meetings, etc.); making contacts with key regulatory personnel in each country "whose hoops they have to jump through;" and understanding the regulatory climate in foreign markets. Their ability to develop rapport with authorities along with the knowledge about regulations, approval cycles, and regulatory agency operations, gives them a definite advantage in gaining access to new markets. One company labeled this benefit as an "opportunity cost" which to them meant a saving because of the shortened time to have new product designs approved and marketed overseas due to early access to knowledge not possessed by their competition. 
- Market Enhancement

All of the companies also cited a number of benefits which are classified as "market enhancement" because of their potential for improving product sales. These include such subtle, yet significant, advantages as product recognition, exchange of technical data, outlets for publicity, and the opportunity to influence provisions in standards in favor of U.S. products.

\section{- Economies in Operation}

Time and money are saved at many stages of design, tooling, production, and testing because procedures are improved and simplified. Large numbers of slightly different parts or subassemblies, for example, can be reduced to a relatively small number of standard parts to meet all needs. Efficiencies result in the production, stocking and marketing of products for a wider range of foreign markets.

\subsection{Disadvantages}

The interviewees did point out some disadvantages that can result from active participation in international standards work. These are listed in Table 4. For the most part, the firms felt that they were more likely to disclose proprietary information and also expose potential trade information to others, possibly their competitors. The adoption of international standards also left their markets vulnerable--even in the U.S. One company felt that too many restrictive or unnecessary provisions in a standard tend to reduce available design and development freedom. The use of standards provisions to solve non-problems, address political problems, or the adoption of provisions without a sound technical or scientific base were also cited as disadvantages which can and sometimes do exist in the international standards area.

However, all the interviewees indicated that the benefits they have experienced far outweigh the disadvantages and costs of participation. By aggressive action and prudent maneuvering in standards committees, many of the disadvantages can be negated and strategies adopted to turn them into benefits.

\section{OTHER STUDIES RELATED TO BENEFITS PERCEIVED BY INDUSTRY FROM STANDARDS PARTICIPATION}

The author has been unable to locate or identify any earlier studies that have examined the economic benefits of participation in international

standardization activities. In view of the reported difficulty of directly quantifying the benefits from participation in such activities, it is hardly surprising that there are wide variations in the benefit-cost ratio figures given by various firms in the U.S. and other countries from their own "in-house" standards programs. A Canadian study, [7] for example, has reported returns as high as $\$ 50$ per $\$ 1.00$ spent on standards work. Other survey results over a wide range of companies, however, suggest that a return of $\$ 5$ per $\$ 1.00$ invested in standards activities is a more reasonable expectation. 
A survey [8] concerning the benefits of standardization in nearly 900 companies in France showed that about $50 \%$ of the savings were in the area of production, with the remainder split between purchasing and stocking. Studies [9] in the Federal Republic of Germany indicated that the overall return on investment was in the order of $7: 1$ when all direct and indirect costs were taken into account. In the USSR, the national average ratio was reported as $7.5: 1$, based on:

0 Electrotechnical industries...................35:1

- Mechanical engineering, transport, electronics and telecommunications industries....4.6 to $7.9: 1$

o Construction, timber \& chemical industries.......0.6 to 2.1:1

In 1976, the Aerospace Industries Association (AIA), recognizing the need for undertaking an active leadership role in international standardization, assumed the secretariat of the key international committee for aerospace standardization, Technical Committee 20, "Aircraft and Space Vehicles," of the International Organization for Standardization. A report issued in 1982 [10] predicts that international standards will play an increasingly important role in the future of the U.S. aerospace industry.

In a paper presented at the Thirty-second Annual Conference of the Standards Engineering Society, it was indicated by a Senior Standards Engineer from Honeywe11, Inc. that "many of the benefits of standardization are intangible or at best difficult to measure" [11] and that there are unexpected side benefits from standardization.

A book published by the International Organization for Standardization (ISO) entitled "Benefits of Standardization" [12] discusses in general the value of all types of standards. Various methods and concepts for applying complex economic structures are offered for the evaluation of impact at the company, national or international level. These might be useful to analysts seeking a quantitative approach, assuming that data are available.

Thirty years ago, the American Standards Association (now ANSI - American National Standards Institute) conducted a series of wide-ranging surveys to obtain data on savings derived from the use of standards by American industry. Their first report [13] describes a body of savings based on 79 documented case studies covering 27 industrial fields. There was unanimous agreement that standards were essential and the interviewed companies generally recognized that savings resulted from standards work whether or not they could be measured. The 1959 study [14] provides survey findings from 209 companies, 34 of which reported actual dollar savings ranging up to $\$ 50$ saved per dollar spent on standards work.

Another paper [15] describes the development of National Aerospace Standard (NAS) 1524 [16] and additional cost factors based on industry-wide surveys and specialized sources. NAS 1524 is a compilation of accepted methods of calculating the costs and benefits of standardization and is recognized as an early guide to the application of economic analysis to standardization. 
A recent monograph [17] addresses the relationship between economics, standardization and management in an organization. It is intended as a primer for management providing basic principles which can be tailored to specific circumstances and requirements. Other approaches at characterizing the benefits yielded via standardization are discussed in a 1975 text on industry standards.[18] These benefits include interchangeability, economy of scale and information benefits.

\section{CONCLUSIONS AND RECOMMENDATIONS}

\subsection{Conclusions}

A11 the firms interviewed (and the others initially contacted) have a strong management commitment and strategy for involvement and a stake in the outcome. They realize that standards will be published by international organizations whether or not U.S. industry participates in their development. If American companies express no interest or make no attempt to present the ir points of view in the writing of such standards, they and their industries will likely forgo the benefits identified by this study. In contrast, the industries of almost all other nations, acting in what has become a fiercely competitive international market, emphatically represent their own best interests on every possible occasion. Even though the benefits and the costs cannot be directly measured by dollars and cents on the profit and loss statements, their effect is considered to be significant. All interviewees' companies intend to maintain their involvement and active participation in the future. However, it is apparent from discussions with the many firms contacted and those five actually interviewed, and also from discussions with ANSI staff members, that we do not have a good measure on how much money American industry invests in international standardization activities. This seems to indicate that most U.S. firms do not financially monitor the ir standards work as an explicit budget item (profit center), nor are they aware of the potential benefits that can accrue from participation in international standards activities. Other conclusions that can be substantiated are as follows:

1. Underwriting the costs of participating is not reported as a problem area. In part, this may be due to the fact that the firms surveyed are internationally structured with existing overseas marketing and/or manufacturing operations. The participation budgets are generally included in the company's other cost centers rather than as single line items. Most often, these costs are charged to centers related to products under the heading of quality (quality assurance) or product development and planning, but not under research and development, for example.

2. The motives for involvement are related to meeting or beating domestic and foreign competitors in export markets and to defend against the strategies of competitors to influence standards actions. These companies seek to exploit their own technological strengths; recognize and adapt to "acceptable" developments elsewhere; or strive to prevent adoption of "undesirable" proposals made by others. In effect, there is considerable concern that international standards written without U.S. participation may adversely affect the export of U.S. goods and services. 
3. Participation provides an opportunity to keep informed of what others are doing and to be aware of the different cultural backgrounds of consuming countries.

4. The interviewed companies consider the benefits of participation to be significant even though not demonstrated in a quantifiable sense. Adoption of international standards puts all suppliers on a fair competitive basis, thereby stimulating competition.

5. The anticipated benefits -- enhanced markets, informed readiness and economies in operation can be achieved only by continuing (stable) representation on appropriate international groups by committed industry experts.

These results suggest that planned company activities in standardization programs are an effective means of producing real economies or for increasing trade. U.S. industry should consider participation in the development of international standards to ensure that they incorporate the viewpoint of U.S. interests and recognize U.S. standards and engineering practices.

\subsection{Recommendations}

1. Participate in those committees and working groups of international standards-making organizations where U.S. economic interests are appreciable.

2. Ensure continuity of expert representation at committee and working group meetings to express U.S. viewpoints and technical positions effectively.

3. Seek to discover parallels with successful experiences in domestic standards activities that may be applicable to international activities as possible reinforcement of the benefits of participation reported herein.

4. Explore in future studies the successes of U.S. delegations to various international standards bodies as related to the trade characteristics and growth trends of the industries they serve; the competency, skills and commitment of individuals attending technical meetings and their impact on protecting or expanding markets; and whether affected industries are internationally structured or primarily national in character.

5. Supplement the findings of this study of large firms with extensive overseas markets or manufacturing operations by examination of the participation by small and medium size firms that do not have manufacturing operations overseas.

6. Consider whether it is to the best interest of industry groups, technical societies and trade associations to underwrite some of the expenses of delegates to international standards meetings to help small-to-medium size firms meet participation costs, which have risen dramatically as a result of inflation and the accelerated pace of international standards activity. 
7. Provide coverage for possible new or increased trade opportunities for U.S. businesses that result from such meetings through reports prepared by delegates upon return from technical committee or working group meetings. Even the most subtle information on foreign markets or customs may provide an otherwise overlooked trade opportunity for a U.S. company.

\section{FUTURE STUDIES}

The NBS Office of Product Standards Policy will compile further information on the economic benefits and costs that U.S. industry has realized from international standardization activities; hence, individual companies or trade associations are encouraged to report on their experiences in expanding trade or protecting markets through involvement in international standardization. Documented examples of benefits are especially desired. Future studies in this series will include examples of information received in response to this request. Presentation of individual case studies will protect names of firms, individuals and products if the provided information is identified as confidential or proprietary. The underlying precept is that the potential economic or other benefits of involvement in international standards development activities can be extended in many cases across company and industry lines to the mutual benefit of all concerned.

\section{REFERENCES}

[1] Sec. 413. - Representation of U.S. Interests Before International Standards Organizations.

[2] The Agreement on Technical Barriers to Trade (popularly called the "Standards Code") entered into force in 1980.

[3] "Report on Major United States Export Areas and International Standards Activities," National Bureau of Standards, Office of Product Standards Policy; April 1983.

[4] Business America, U.S. Department of Commerce, International Trade Administration, February 20, 1984, p. 2.

[5] The American National Standards Institute (ANSI) estimates that representatives from between 1500 and 2000 U.S. firms make up the 2200 Technical Advisory Groups (TAG's) responsible for participation in technical committee work of international standardization bodies. Large corporations with multi-national interests seem to predominate in this group of most-actively involved U.S. firms.

[6] "Directory of International and Regional Organizations Conducting Standards Related Activities," SP-649, National Bureau of Standards, April 1983.

[7] "Standardization is Good Business," R. P. Preston, Standards Council of Canada; Ottowa; June, 1978, p. 7. 
[8] Ibid., p. 9.

[9] Ibid., p. 10.

[10] "Impact of International Standardization Trends in the U.S. Aerospace Industry," Aerospace Industries Association of America, Inc.; Washington, D.C.; June 1982.

[11] Joshi, Mohan N. "Planned Standardization -- A Key to Productivity," Proceedings, Thirty-Second Annual Conference, Standardization Engineering Society, September 1983, Dayton, OH pp. 53-61.

[12] "Benefits of Standardization;" International Organization for Standardization; Geneva, 1982.

[13] "Dollar Savings Through Standards," American Standards Association, New York, 1955.

[14] "Company Standardization, Organization, Costs and Savings," American Standards Association, New York, 1959.

[15] Toth, Robert B., "The Economics of Standardization: Credits vs. Debits." Standards Engineering, Vol. 24, No. 2, April 1972.

[16] Aerospace Industries Association, National Aerospace Standard 1524, Standardization Savings, Identification and Calculation, Revision 3 , Sept. 1971.

[17] Toth, Robert B., "The Economics of Standardization -- A Pragmatic Approach," McLean, VA, 1983.

[18] Hemenway, David, "Industrywide Voluntary Product Standards", Ballinger Publishing Co., Cambridge, MA. 
Table 1. Characteristics of Companies

\begin{tabular}{|c|c|c|c|c|c|}
\hline & Company & Company & Company & $\begin{array}{l}\text { Company } \\
\text { D }\end{array}$ & Company \\
\hline PRODUCT LINE & $\begin{array}{l}\text { Electronic } \\
\text { Components }\end{array}$ & $\begin{array}{l}\text { Process } \\
\text { Control } \\
\text { Systems }\end{array}$ & $\begin{array}{l}\text { Building } \\
\text { Products }\end{array}$ & $\begin{array}{l}\text { Medical } \\
\text { Devices }\end{array}$ & $\begin{array}{l}\text { Portabie } \\
\text { Equipment }\end{array}$ \\
\hline $\begin{array}{l}\text { TOTAL ANNUAL SALES } \\
\text { (\$ in Millions) }\end{array}$ & $\$ 170$ & $\$ 600$ & $\$ 1300$ & $\$ 340$ & $\$ 1500$ \\
\hline $\begin{array}{l}\text { NO. MANUFACTURING } \\
\text { PLANTS (U.S./Foreign) }\end{array}$ & $6 / 4$ & $15 / 7$ & $39 / 10$ & $7 / 4$ & $60 / 0$ \\
\hline $\begin{array}{l}\text { NO. EMPLOYEES } \\
\text { (U.S./Foreign) } \\
\end{array}$ & $N / A$ & $9000 / 3500$ & 21000/Total & $4700 /$ Total & $11000 / 0$ \\
\hline $\begin{array}{l}\text { MAJOR OVERSEAS } \\
\text { MARKETS }\end{array}$ & $\begin{array}{l}\text { Europe } \\
\text { Japan } \\
\text { Canada }\end{array}$ & $\begin{array}{l}\text { Europe } \\
\text { S. America } \\
\text { Canada }\end{array}$ & $\begin{array}{l}\text { Europe } \\
\text { Canada } \\
\text { Australia } \\
\end{array}$ & $\begin{array}{l}\text { Europe } \\
\text { Japan } \\
\text { Latin Amer. }\end{array}$ & $\begin{array}{l}\text { Europe } \\
\text { Canada } \\
\text { Australia }\end{array}$ \\
\hline $\begin{array}{lc}\text { INT'L STDS. (No. of } & \text { ISO } \\
\text { PARTICIPA- Tech. } & \text { IEC } \\
\text { IION } \quad \text { Cmtes.) } & \text { other } \\
\end{array}$ & 2 & $\begin{array}{l}1 \\
2 \\
1\end{array}$ & 1 & $\begin{array}{l}1 \\
2\end{array}$ & 1 \\
\hline
\end{tabular}


Table 2. Needs Cited by Companies

\begin{tabular}{|c|c|c|c|c|c|c|c|}
\hline $\begin{array}{l}\text { MOTIVATING FACTORS/PERCEIVED } \\
\text { NEEDS FOR PART ICIPATION: }\end{array}$ & $\begin{array}{c}\text { Company } \\
A\end{array}$ & $\begin{array}{c}\text { Company } \\
\text { B }\end{array}$ & $\begin{array}{l}\text { Company } \\
\mathrm{C}\end{array}$ & $\begin{array}{l}\text { Company } \\
\text { D }\end{array}$ & $\begin{array}{c}\text { Company } \\
E\end{array}$ & CAT. & $\overline{\mathrm{NO}}$ \\
\hline $\begin{array}{l}0 \text { Defensive Action (Taken to } \\
\text { Counter Foreign Competition) }\end{array}$ & $r$ & + & & & \pm & C & 3 \\
\hline $\begin{array}{l}\text { Need for Universal Product } \\
\text { or Test Method Standard }\end{array}$ & + & + & + & + & + & $\mathrm{T}$ & 5 \\
\hline $\begin{array}{l}\text { - Advance U.S. Position in } \\
\text { Standards Development }\end{array}$ & + & + & & + & + & C & 4 \\
\hline $\begin{array}{l}\text { O.S. Markets Stabilized - } \\
\text { Expand Sales Via Exports }\end{array}$ & + & & & & + & $M$ & 2 \\
\hline $\begin{array}{l}\text { O U.S. Competitors Involved } \\
\text { in Exporting }\end{array}$ & \pm & & & & & C & 1 \\
\hline $\begin{array}{l}\text { Influence of End-Item Users } \\
\text { in Adopting Int'l } 1 \text { Standards }\end{array}$ & + & & & & & $M$ & 1 \\
\hline $\begin{array}{l}\text { - Maintain Product Compatibi- } \\
\text { lity (e.g.; Electro-Mech. } \\
\text { Interfaces) }\end{array}$ & + & & & & & $M$ & 1 \\
\hline $\begin{array}{l}\text { - Inadequate U.S. Standards } \\
\text { Available }\end{array}$ & & + & & & & $\mathrm{T}$ & 1 \\
\hline $\begin{array}{l}\text { - Centralized Control of Product } \\
\text { Design/Performance for All } \\
\text { Markets }\end{array}$ & & + & + & & & $M$ & 2 \\
\hline $\begin{array}{l}\text { Long Established Overseas } \\
\text { Presence }\end{array}$ & & + & & & & $M$ & 1 \\
\hline $\begin{array}{l}\text { o Rapid State-of-Art Advances } \\
\text { in Technology }\end{array}$ & + & + & & + & & A & 3 \\
\hline $\begin{array}{l}\text { Desire to Minimize Regulatory } \\
\text { Surprises }\end{array}$ & & + & + & + & & $T$ & 3 \\
\hline $\begin{array}{l}\text { - Substantial Budget for Product } \\
\text { Testing for Regulatory Approvals }\end{array}$ & & & + & + & & $\mathrm{T}$ & 2 \\
\hline $\begin{array}{l}\text { Regulatory Approval Process } \\
\text { Differs Significantly Among } \\
\text { Countries }\end{array}$ & & & + & \pm & & $\mathrm{T}$ & 2 \\
\hline $\begin{array}{l}\text { - Interpretation Conflicts in } \\
\text { Standards Cause Expensive Delays }\end{array}$ & & & + & \pm & & $T$ & 2 \\
\hline
\end{tabular}

Summary

Primary Motivating Factors:
Category
Title
No. of Times
Category Cited

$\%$ of Total Times

Category Cited

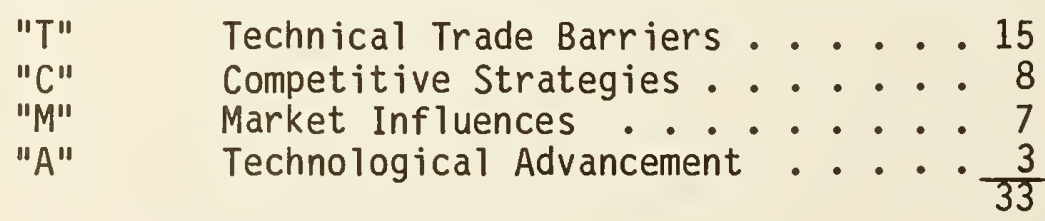




\begin{tabular}{|c|c|c|c|c|c|c|c|}
\hline SUMMARY OF BENEFITS CITED: & Company & $\underset{B}{\text { Company }}$ & $\begin{array}{c}\text { Company } \\
C\end{array}$ & $\begin{array}{c}\text { Company } \\
\text { D }\end{array}$ & Company & CAT. & NO. \\
\hline $\begin{array}{l}\text { - Influence/Control Committee } \\
\text { Business (Agendas, Ballots, } \\
\text { Timing, etc.) }\end{array}$ & + & & & & & $R$ & 1 \\
\hline $\begin{array}{l}0 \text { Reduced Costs for Design, } \\
\text { Tooling, Production, Testing }\end{array}$ & + & + & & & & $E$ & 2 \\
\hline $\begin{array}{l}\text { Contributes to Broader } \\
\text { Market Base for Exports }\end{array}$ & + & & + & + & + & $E$ & 4 \\
\hline $\begin{array}{l}\text { O Eliminates Need for DuaT } \\
\text { Production Lines } \\
\end{array}$ & + & & & & & $E$ & 1 \\
\hline $\begin{array}{l}\text { Source of Knowledge on } \\
\text { Foreign Technology }\end{array}$ & + & + & & + & + & $R$ & 4 \\
\hline $\begin{array}{l}\text { - Better Recognition of Products } \\
\text { in Marketplace }\end{array}$ & + & + & & & & $M$ & 2 \\
\hline $\begin{array}{l}\text { - Shortened Time Interval to } \\
\text { Market New Designs }\end{array}$ & & + & & + & & $E$ & 2 \\
\hline $\begin{array}{l}\text { - Basis for Establishing Equiva- } \\
\text { lency for Similar but Different } \\
\text { Products(Functional Equivalency) }\end{array}$ & & & + & & & M & 1 \\
\hline $\begin{array}{l}\text { Facilitates Product Approval } \\
\text { Process in Foreign Governments }\end{array}$ & & & + & + & & $R$ & 2 \\
\hline $\begin{array}{l}\text { - Improves Access to Regulatory } \\
\text { Authorities }\end{array}$ & & & + & + & & $R$ & 2 \\
\hline $\begin{array}{l}\text { Well-Informed Compliance } \\
\text { Facilitates Sales } \\
\end{array}$ & & & + & + & & $R$ & 2 \\
\hline $\begin{array}{l}0 \text { Establishes Contacts for } \\
\text { Potential Entry Into New Markets }\end{array}$ & & & + & + & + & M & 3 \\
\hline $\begin{array}{l}\text { - Provides Outlet for Marketing } \\
\text { Info. on Foreign Cultures, } \\
\text { Preferences, etc. }\end{array}$ & & & & + & & $M$ & 1 \\
\hline $\begin{array}{l}\text { O Provides Forum for Exchange of } \\
\text { Ideas }\end{array}$ & & + & & & + & $R$ & 2 \\
\hline $\begin{array}{l}\text { Higher Quality Standard Results } \\
\text { From U.S. Presence } \\
\end{array}$ & + & & & + & + & $M$ & 3 \\
\hline
\end{tabular}

Summary

Allocation of Benefits:

Category

Title

No. of Times

Category Cited

"R" Informed Readiness ...... 13

"M" Market Enhancement ...... 10

"E" Economics in Operation .... $\frac{9}{32}$
$\%$ of Total Times

Category Cited

41

31

28 
Table 4. Disadvantages Cited by Companies

\begin{tabular}{|c|c|c|c|c|c|c|}
\hline SUMMARY OF DISADVANTAGES CITED: & Company & $\begin{array}{c}\text { Company } \\
B\end{array}$ & Company & $\begin{array}{c}\text { Company } \\
D\end{array}$ & Company & \\
\hline $\begin{array}{l}\text { Allows Access to U.S. Markets } \\
\text { By Foreign Competitors }\end{array}$ & $n$ & 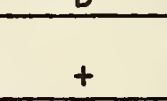 & & 4 & - & 4 \\
\hline $\begin{array}{l}\text { O More Likely to Share/Expose } \\
\text { Proprietary Information }\end{array}$ & & + & + & & & 2 \\
\hline $\begin{array}{l}\text { - Standards May Reduce "Degrees } \\
\text { of Freedom" for Co. and Design } \\
\text { Liberties }\end{array}$ & & & & + & & 1 \\
\hline $\begin{array}{l}\text { Some Standards Developed w/o } \\
\text { Scientific Rationale or to } \\
\text { Solve "Non-Problems" }\end{array}$ & & & & + & & 1 \\
\hline
\end{tabular}


4. TITLE AND SUBTITLE

Benefits Perceived by U.S. Industry from Participating in International Standards Activities

5. $\operatorname{AUTHOR}(S)$

Patrick W. Cooke

6. PERFORMING ORGANIZATION (If joint or other than NBS, see instructions)

7. Contract Grant No.

NATIONAL BUREAU OF STANDARDS

DEPARTMENT OF COMMERCE

WASHINGTON, D.C. 20234

8. Type of Report \& Period Covered

Final

9. SPONSORING ORGANIZATION NAME AND COMPLETE ADDRESS (Street, City. State, ZIP)

Same as in Item 6 above.

10. SUPPLEMENTARY NOTES

Document describes a computer program; SF-185, FIPS Software Summary, is attached.

11. ABSTRACT (A 200-word or less factual summory of most significant informotion. If document includes a significant bibliogrophy or literature survey. mention it here)

This report describes the results of a limited study to assess the extent to which U.S. industry profits by virtue of participation in the comittee activities of international standardization organizations. The substantial trade benefits that can accrue are identified and evaluated in terms of the needs of the firms surveyed and the potential opportunities for new or increased foreign trade. Recommendations are given for industry to become more aware of the cost-effectiveness of participation and to extend the potential benefits to other firms and industries.

12. KEY WORDS (Six to twelve entries; alphabetical order; capitalize only proper names: and separate key words by semicolon s) Benefits; cost effectiveness; exports; foreign trade; internatianal bodies; international standards; standards development; trade barriers; U.S. industry

13. AVAILABILITY

[E] Unlimited

For Official Distribution. Do Not Release to NTIS

$\square$ Order From Superintendent of Documents, U.S. Government Printing Office, Washington, D.C. 20402

[X] Order From National Technical Information Service (NTIS), Springfield, VA, 22161
14. NO. OF PRINTED PAGES

23

15. Price

$\$ 7.00$ 


